Research

\title{
Phenotypic and Genotypic Study of Antibiotics Resistance Profile in Escherichia coli Isolated from Broilers Farm in Cianjur, Indonesia
}

\section{Kajian Fenotip dan Genotip Profil Resistensi Antibiotik pada Escherichia coli yang Diisolasi dari Peternakan Ayam Broiler di Cianjur, Indonesia}

\author{
Aprilia Hardiati', Safika', I Wayan Teguh Wibawan', Fachriyan Hasmi Pasaribu' \\ ${ }^{1}$ Medical Microbiology Division, Department of Animal Infectious Diseases and Veterinary Public Health, \\ Faculty of Veterinary Medicine, IPB University, Indonesia \\ *Corresponding author: fhpasaribu@gmail.com \\ Submitted 24 Februari 2021, Accepted 29 Mei 2021
}

\begin{abstract}
This study aimed to investigate the phenotypic and genotypic of antibiotics resistance profile in Escherichia coli. The 30 samples come from cloacal swab of broilers in Cianjur, Indonesia. Isolation and identification of E. coli was performed by culturing in McConkey agar, eosin methylene blue agar, Gram staining and five essential biochemical tests (indole, methyl red, Voges-Proskauer, and citrate). In this study, 10 isolates (33.3\%) were confirmed E. coli positive. Phenotypic profile was performed by screening all isolates with 8 antibiotics of 6 antibiotic groups. The screening was carried by Kirby-Bauer disk diffusion method based on the standard of CLSI. For genotypic profile, each resistant isolate was detected antibiotic resistance-encoding gene. The result showed all isolates (100\%) resistant against tetracyclin, oxytetracycline and erythromycin. Nine isolates (90\%) detected nalidixic acid and enrofloxacin-resistant. The ciprofloxacin and gentamicin-resistant isolates were $70 \%$ and $40 \%$, respectively. There was no resistant isolate for chloramphenicol. Multi drug-resistant was detected on $90 \%$ isolates. Only gyrA (100\%) and tetA (80\%) genes were detected. This study showed high rate of occurrence of antibiotic resistance in E. coli. Not all resistant isolates were detected to have target genes encoding antibiotic resistance in this study.
\end{abstract}

Keywords: Escherichia coli, broiler, antibiotic resistance, phenotypic, genotypic

\begin{abstract}
ABSTRAK
Penelitian ini bertujuan untuk mengetahui fenotip dan genotip profil resistensi antibiotik pada Escherichia coli. Sampel yang digunakan diambil dari swab kloaka ayam pedaging di Cianjur, Indonesia. Isolasi dan identifikasi E. coli dilakukan dengan membiakkan pada agar McConkey, agar eosin metilen biru, pewarnaan Gram dan uji biokimia esensial (indole, methyl red, Voges-Proskauer, dan sitrat). Sepuluh isolat (33,3\%) dikonfirmasi positif E. coli. Identifikasi profil fenotip dilakukan dengan melakukan penyaringan semua isolat dengan 8 antibiotik dari 6 kelompok antibiotik. Penyaringan dilakukan dengan metode difusi cakram Kirby-Bauer berdasarkan standar CLSI. Identifikasi profil genotip masing-masing isolat dilakukan dengan deteksi gen penyandi resistensi antibiotik. Hasil penelitian menunjukkan semua isolat $(100 \%)$ resisten terhadap tetrasiklin, oksitetrasiklin dan eritromisin. Sembilan isolat (90\%) mendeteksi asam nalidiksat dan resisten terhadap enrofloksasin. Isolat yang resisten terhadap ciprofloxacin dan gentamisin adalah $70 \%$ dan $40 \%$. Tidak ada isolat yang resisten terhadap kloramfenikol. Resistensi karena beberapa jenis obat (multi drugresistant) terdeteksi pada $90 \%$ isolat. Gen yang terdeteksi hanya gyrA (100\%) dan tetA (80\%). Penelitian ini menunjukkan tingginya angka kejadian resistensi antibiotik pada $E$. coli. Tidak semua isolat resisten terdeteksi memiliki target gen penyandi resistensi antibiotik dalam penelitian ini.

Kata kunci: Escherichia coli, broiler, resistensi antibiotic, fenotip, genotip
\end{abstract}




\section{INTRODUCTION}

Antibiotic resistance has become an increasingly uncontrollable health problem in recent years. Global awareness of the emergence of multi drugresistant bacteria (MDR) has increased but new MDR strains have also increased (Solomon \& Oliver, 2014). Therefore, the health threat due to MDR bacterial infection is increasing (Mohammad et al., 2015) Antibiotic resistance can lead to ineffectiveness of standard treatment, persistent infection, and can spread to other individuals (WHO, 2019). Patients with these infections need a more complicated treatment plan because of the ability of bacterial cells to fight off antibiotics, resulting in higher morbidity and mortality rates (Bonomo, 2000). The United States Centers for Disease Control and Prevention (CDC) estimated in 2013 that at least 2 million people acquire antibiotic-resistant bacterial infections each year and more than 23 thousand people die from these infections (Mohammad et al., 2015).

Improper use of antibiotics in livestock, farms, domestic animals, plants and humans causes antibiotic resistance in agricultural and clinical biomes. Antibiotic resistance to pathogenic bacteria is caused by the widespread and uncontrolled use of antibiotics in agricultural and medical (Cameron \& McAllister, 2016). Many countries in the world have made substantial efforts to reduce the use of antibiotics in food-producing animals. These efforts include establishing national reduction targets, implementing a ban on antibiotics in animal feed for food-producing animals, comparing the use of antibiotics at the farm level, and encouraging antibiotic stewardship such as requiring susceptibility testing prior to the use of high priority antibiotics. This kind of intervention is expected to reduce the rate of antibiotic resistance in animals, the environment, and in humans (Karen et al., 2017).

Escherichia coli, including the family Enterobacteriaceae, acts as commensal bacteria and pathogens. They can be found in the environment, food, animal intestines, and human intestines (Markey et al., 2013). It is known that $E$. coli is a bacterium that has antibiotic resistance properties (Kurnia et al., 2018). According to WHO (2017), E. coli is the main bacterial cause of the spread of antibiotic resistance. It expresses the MDR mechanism by multiple and varied mechanisms i.e. changing the target site to prevent antibiotic binding, stopping the active pump of the antibiotic entry pathway into cells and impaired absorption of antibiotics due to reduced outer membrane permeability (Tilak, 2011). Expression of antibiotic resistance mechanisms encoded by certain genes. Bacteria that are resistant to more than one antibiotic class also have more than one resistance coding gene. Even bacteria that are resistant to one antibiotic can have more than one resistance coding gene. Tetracycline-resistant E. coli was detected to have the tet $A$ and tet $B$ genes; quinolone resistance was detected to have the $q n r A, q n r B$, and $q n r S$ genes (Kurnia et al., 2018).

Among Gram negative bacteria, E. coli has the highest resistance pattern (Sukhumungoon et al., 2011). Antibiotic resistance testing is important to understand and monitor the pattern of antibiotic resistance conditions in E. coli, especially those from production animals. Therefore, the main objective of this study was to investigate the phenotype and genotype phenotypic and genotypic profile of antibiotic resistance in $E$. coli isolated from cloacal swab samples of broilers.

\section{MATERIALS AND METHODS}

\section{Materials}

Materials used in this study were thirty cloacal swab samples from broilers, $0.1 \%$ buffered peptone water (Oxoid CM1049, Thermo Scientific, England), tryptone soya agar (Oxoid CM0131, Thermo Scientific, England), MacConkey agar (Oxoid CMoo07, Thermo Scientific, England), eosin methylene blue agar (Levine) (L-EMB) (Oxoid CMoo69, Thermo Scientific. England), methyl red-Voges Proskauer (MR-VP) medium (Oxoid CMoo43, Thermo Scientific, England), Kovacs indole reagent (1.09293.0100 Milipore, Merck, Germany), KOH 40\%, Mueller Hinton agar (MHA) (Oxoid CM0337, Thermo Scientific, England), tryptone soya broth (Oxoid CM0129, Thermo Scientific England), antibiotic disks, i.e. tetracycline (TE) $30 \mu \mathrm{g}$ (Oxoid OT 30 CT0054B, Thermo Scientific, England), oxytetracycline (OT) $30 \mu \mathrm{g}$ (Oxoid OT 30 CTo041B, Thermo Scientific, England), gentamicin (CN) $10 \mu \mathrm{g}$ (Oxoid $\mathrm{CN}$ 10 CT0024B, Thermo Scientific, England), nalidixic acid (NA) $30 \mu \mathrm{g}$ (Oxoid NA 30 CTo031B, Thermo Scientific, England), ciprofloxacin (CIP) $5 \mu \mathrm{g}$ (Oxoid CIP 5 CT0425B, Thermo Scientific, England), enrofloxaCin (ENR) $5 \mu \mathrm{g}$ (Oxoid ENR 5 CT0639B, Thermo Scientific, England), chloramphenicol ( $C L) 30 \mu g$ (Oxoid CL 30 CTo013B, Thermo Scientific, England), and erythromycin (E) $15 \mu \mathrm{g}$ (Oxoid E 15 CTo020B Thermo Scientific, England), Presto ${ }^{T M}$ Mini gDNA bacteria kit (GBB300/301, Geneaid, Taiwan), MyTaq ${ }^{\mathrm{TM}}$ HS Red Mix (Bioline BIO-25048, England), FloroSafe DNA Stain (BIO-5130, 1st 
BASE, Malaysia), 100 bp DNA ladder (Invitrogen 15628019, Thermo Scientific, USA), BlueJuice ${ }^{\text {TM }}$ Gel Loading Buffer (10X) (Invitrogen 10816015, Thermo Scientific, USA), Tris-Acetate-EDTA (TAE) buffer (1x) (T9650, Sigma-Aldrich, Germany) was carried at 70 Volt 50 minutes by electrophoresis power supply Bio-Rad Power Pac 300 (15008 C24, Bio-Rad, California).

\section{Samples Collection}

Thirty cloacal swab samples were collected from broilers at a farm in Cianjur, West Java, Indonesia. Each sample was placed into tube containing $5 \mathrm{ml}$ of $0.1 \%$ buffered peptone water (Oxoid CM1049, Thermo Scientific, England), and labelled with the identity of the sample. All of samples were stored in a cool box with a temperature of $4-10{ }^{\circ} \mathrm{C}$ and immediately taken to the Medical Microbiology Laboratory, Faculty of Veterinary Medicine, IPB University.

\section{Isolation and Identification of Escherichia coli}

The samples were cultured into MacConkey agar (Oxoid CMoo07, Thermo Scientific, England) and incubated at $37^{\circ} \mathrm{C}$ for $18-24$ hours. The pink colonies surrounded by pink on the media because of acidic conditions resulting from lactose fermentation were transferred into eosin methylene blue agar (Levine) (L-EMB) (Oxoid CMoo69, Thermo Scientific. England) and incubated at $37^{\circ} \mathrm{C}$ for $18-24$ hours. The expected E. coli colonies were shown as methalic sheen color. A suspicious colony from each eosin methylene blue agar (Levine) (L-EMB) (Oxoid CMo069, England) plate inoculated to tryptone soya agar (Oxoid CM0131, England) slant and incubated for $18-24$ hours at $37^{\circ} \mathrm{C}$ for further test. Gram staining of suspicious colonies was carried out to determine bacterial cell morphology. The five essential biochemical tests were carried out for confirmation consisting of indole, methyl red, Voges-Proskauer, and citrate (IMViC). All cultures that produced IMViC patterns of ++-- were considered to be $E$. coli (Markey et al., 2013).

\section{Antibiotics Resistance Test}

Antibiotic resistance test was conducted to all E. coli colonies isolated from cloacal swab samples. Test referred Clinical and Laboratory Standards Institute guidelines (CLSI, 2018) using the KirbyBauer disk diffusion method. Nine antibiotics were used in this test, i.e. . tetracycline (TE) $30 \mu \mathrm{g}$ (Oxoid OT 30
CT0054B, Thermo Scientific, England), oxytetracycline (OT) $30 \mu \mathrm{g}$ (Oxoid OT 30 CTo041B, Thermo Scientific, England), gentamicin ( $\mathrm{CN}$ ) $10 \mu \mathrm{g}$ (Oxoid $\mathrm{CN}$ 10 CTo024B, Thermo Scientific, England), nalidixic acid (NA) $30 \mu \mathrm{g}$ (Oxoid NA 30 CTo031B, Thermo Scientific, England), ciprofloxacin (CIP) $5 \mu \mathrm{g}$ (Oxoid CIP 5 CT0425B, Thermo Scientific, England), enrofloxacin (ENR) $5 \mu \mathrm{g}$ (Oxoid ENR 5 CT0639B, Thermo Scientific, England), chloramphenicol ( $C L) 30 \mu g$ (Oxoid CL 30 CTo013B, Thermo Scientific, England), and erythromycin (E) $15 \mu \mathrm{g}$ (Oxoid E 15 CTo020B Thermo Scientific, England). Bacterial colonies that had been grown on tryptone soya agar for 24 hours at $37^{\circ} \mathrm{C}$ were suspended in physiological $\mathrm{NaCl}$ and then matched with 0.5 McFarland standard $\left(1-2 \times 10^{8}\right.$ CFU/ml). Bacterial was cultured spread on Mueller Hinton Agar (Oxoid CM0337, Thermo Scientific, England) surface and left for \pm 5 minutes. The disks contained antibiotic were put on Mueller Hinton Agar (Oxoid CM0337, Thermo Scientific, England). The cultured bacteria were incubated at $35^{\circ} \mathrm{C}$ for $16-18$ hours. Inhibition zones formed were then measured. The categories of susceptible, intermediate, and resistant were based on the size of the according to the standard of CLSI 2018.

\section{Preparation DNA Template}

Escherichia coli isolates were inoculated into tryptone soya broth (Oxoid CM0129, Thermo Scientific England)and incubated for $18-24$ hours at $37^{\circ} \mathrm{C}$. Bacterial suspension were centrifuged for 1 minute 14.000-16.000 $\times g$ and the pellets were taken for DNA extraction. DNA extraction was using Presto $^{\mathrm{TM}}$ Mini gDNA bacteria kit (GBB300/301, Geneaid, Taiwan) and stored at $-20^{\circ} \mathrm{C}$ for further use.

\section{Detection Antibiotics Resistance Genes}

Detection tetA, aac3-IV, gyrA, and ermB as antibiotics resistace genes in $E$. coli isolates used polymerase chain reaction (PCR) method (Kurnia et al., 2018). This reaction was carried out by MyTaq ${ }^{\mathrm{TM}}$ HS Red Mix (Bioline BIO-25048, England) according manufacturer instruction. Annealing temperature was set according to each of the target genes (Table 1). Electrophoresis for PCR products on $1 \%$ agarose gel and Tris-Acetate-EDTA (TAE) buffer (1x) (T9650, Sigma-Aldrich, Germany) was carried at 70 Volt 50 minutes by electrophoresis power supply Bio-Rad Power Pac 300 (15008 C24, Bio-Rad, California). DNA staining used $2 \mu$ FloroSafe DNA Stain (BIO-5130, 1st BASE, Malaysia). 100 bp DNA ladder (Invitrogen 
100 | Hardiati et al.

Table 1 Primer sequence used for detection antibiotics resistance genes of E. coli

\begin{tabular}{|c|c|c|c|c|}
\hline Gene target & Base sequence & Amplicon & $\begin{array}{c}\text { Annealing } \\
\text { temperature }\end{array}$ & Reference \\
\hline \multirow{2}{*}{ tetA } & (F) $5^{\prime}$-GTA ATT CTG AGC ACT GTC GC-3' & \multirow{2}{*}{$965 \mathrm{bp}$} & \multirow{2}{*}{$62^{\circ} \mathrm{C}$} & \multirow{2}{*}{ Chuah et al., 2018} \\
\hline & (R) $5^{\prime}$-CTG CCT GGA CAA CAT TGC TT-3' & & & \\
\hline \multirow{2}{*}{$\operatorname{aac}(3)-I V$} & (F) $5^{\prime}$-CTT CAG GAT GGC AAG TTG GT-3' & \multirow{2}{*}{286 bp } & \multirow{2}{*}{$55^{\circ} \mathrm{C}$} & \multirow{2}{*}{ Van et al., 2008} \\
\hline & (R) 5'-TCA TCT CGT TCT CCG CTC AT-3' & & & \\
\hline \multirow[b]{2}{*}{ gyrA } & (F) $5^{\prime}-\mathrm{CGA} C \mathrm{CCT}$ TGC GAG AGA AAT-3' & \multirow[b]{2}{*}{626 bp } & \multirow[b]{2}{*}{$62{ }^{\circ} \mathrm{C}$} & \multirow[b]{2}{*}{ Nawaz et al., 2012} \\
\hline & (R) 5'-GTT CCA TCA GCC CTT CAA-3' & & & \\
\hline \multirow{2}{*}{ ermB } & (F) $5^{\prime}-$ GAA AAG GTAC TCA ACC AAA TA-3' & \multirow{2}{*}{639 bp } & \multirow{2}{*}{$54^{\circ} \mathrm{C}$} & \multirow{2}{*}{ Song et al., 2004} \\
\hline & (R) 5'-GTA ACG GTA CTT AAA TTG TTT AC-3' & & & \\
\hline
\end{tabular}

Notes : tetA: for tetracycline and oxytetracycline resistant; aac(3)-IV: gentamicin resistant; gyrA: for nalidixic acid, ciprofloxacin or enrofloxacin resistant; and ermB: for erythromycin resistant

15628019, Thermo Scientific, USA) was used as standard. The gene bands formed were adjusted to DNA marker to determine the approximate base length. The size of the DNA bands that have estimated base lengths were matched with references in Table 1.The detection antibiotics resistance genes were only for resistant isolates.

\section{Data Analysis}

Data were presented in tables and analyzed descriptively.

\section{RESULTS}

On the basis of colonies morphology, biochemical and staining properties, 30 the samples (33.3\%) were E. coli positive. Among $10 \mathrm{E}$. coli isolates, all (100\%) isolates were resistant to tetracycline, oxytetracycline, and erythromycin. Nine isolates (90\%) were resistant to nalidixic acid and enrofloxacin. There were no isolates susceptible to chloramphenicol (20\% intermediate; $80 \%$ susceptible). Seven isolates (70\%) showed resistant against ciprofloxacin and only $4(40 \%)$ isolates were resistant to gentamicin. Nine isolates (90\%) samples showed resistant to more three antibiotics groups (MDR). MDR isolates more three antibiotics groups (MDR). MDR isolates were resistant to TE-OT-CN-NA-ENR-CIP-E or TE-OTNA-ENR-CIP-E. Eight tetracycline and oxytetracycline-resistant isolates $(80 \%)$ had tetA gene. All quinolone and fluoroquinolone-resistant isolates showed positive for gyrA gene. The aac(3)-IV were not detected on all gentamicin-resistant isolates. Erythromycin-resitant isolates were negative for ermB gene (Table 2).

\section{DISCUSSION}

The emergence of antibiotics resistance agents had become a public health threat. Caution was necessary when there were few or no effective alternative antibiotic agents for the treatment of infections caused by E. coli. Although most strains of E. coli were harmless and commonly found in the intestines of humans and warm-blooded animals, some strains could cause severe foodborne disease in humans.

In this study, we studied the phenotype and genotype profile of antibiotic resistance in E. coli from cloacal swabs of broilers in Cianjur, Indonesia. The $33.3 \%$ prevalence of $E$. coli isolates from samples collected in this study was lower than some previous studies (Masruroh et al., 2016; Niasono et al., 2019; Al 
Table 2 Phenotypic and genotypic E. coli isolates

\begin{tabular}{|c|c|c|c|c|c|c|c|c|c|c|c|c|c|}
\hline \multirow{2}{*}{$\dot{\dot{o}} \stackrel{\underline{N}}{\underline{N}}$} & & & & Antib & otics & & & & \multirow{2}{*}{$\begin{array}{l}\text { No. of } \\
\text { Resistant } \\
\text { Groups }\end{array}$} & \multicolumn{4}{|c|}{ Genes } \\
\hline & TE & OT & $\mathrm{CN}$ & NA & ENR & $\begin{array}{l}\mathrm{Cl} \\
\mathrm{P}\end{array}$ & $E$ & $C$ & & tet $A$ & $\operatorname{aac}(3)-I V$ & gyrA & ermB \\
\hline 1 & $\mathrm{R}$ & $\mathrm{R}$ & $S$ & $\mathrm{R}$ & $\mathrm{R}$ & $\mathrm{R}$ & $\mathrm{R}$ & I & 4 & + & $*$ & + & - \\
\hline 2 & $\mathrm{R}$ & $\mathrm{R}$ & $S$ & $\mathrm{R}$ & $\mathrm{R}$ & $\mathrm{s}$ & $R$ & $\mathrm{~S}$ & 4 & + & $*$ & + & - \\
\hline 3 & $\mathrm{R}$ & $R$ & $S$ & $\mathrm{~s}$ & $S$ & $\mathrm{~S}$ & $\mathrm{R}$ & $S$ & 2 & + & $*$ & $*$ & - \\
\hline 4 & $\mathrm{R}$ & $\mathrm{R}$ & $\mathrm{R}$ & $\mathrm{R}$ & $\mathrm{R}$ & $\mathrm{R}$ & $\mathrm{R}$ & I & 5 & - & - & + & - \\
\hline 5 & $\mathrm{R}$ & $\mathrm{R}$ & $\mathrm{R}$ & $\mathrm{R}$ & $\mathrm{R}$ & I & $\mathrm{R}$ & I & 5 & + & - & + & - \\
\hline 6 & $\mathrm{R}$ & $\mathrm{R}$ & $\mathrm{R}$ & $\mathrm{R}$ & $\mathrm{R}$ & $\mathrm{R}$ & $\mathrm{R}$ & $\mathrm{S}$ & 5 & - & - & + & - \\
\hline 7 & $\mathrm{R}$ & $\mathrm{R}$ & $\mathrm{R}$ & $\mathrm{R}$ & $\mathrm{R}$ & $\mathrm{R}$ & $\mathrm{R}$ & $\mathrm{S}$ & 5 & + & - & + & - \\
\hline 8 & $\mathrm{R}$ & $\mathrm{R}$ & $S$ & $\mathrm{R}$ & $\mathrm{R}$ & $\mathrm{R}$ & $\mathrm{R}$ & $S$ & 4 & + & $*$ & + & - \\
\hline 9 & $\mathrm{R}$ & $\mathrm{R}$ & $S$ & $\mathrm{R}$ & $\mathrm{R}$ & $\mathrm{R}$ & $\mathrm{R}$ & $\mathrm{S}$ & 4 & + & $*$ & + & - \\
\hline 10 & $\mathrm{R}$ & $\mathrm{R}$ & $S$ & $\mathrm{R}$ & $R$ & $\mathrm{R}$ & $\mathrm{R}$ & $S$ & 4 & + & $*$ & + & - \\
\hline
\end{tabular}

Notes : TE: tetracycline; OT: oxytetracycline; CN: gentamicin; NA: nalidixic acid; CIP: ciprofloxacin; E: erythromycin; C: chloramphenicol; tetA for tetracycline and oxytetracycline resistant; aac(3)-IV gentamicin resistant; gyrA for nalidixic acid, ciprofloxacin or enrofloxacin resistant; and ermB for erythromycin resistant; S: susceptible; I: intermediate; R: resistant; “+”:antibiotics resistance-encoding gene was present in sample; “_": antibiotics resistance-encoding gene was not present in sample; "*": not performed detection antibiotics resistanceencoding genes because it was not resistant

Azad et al., 2019). However, the results of isolation and identification of $E$. coli in our study were not much different Andriyani et al. (2020) that is $26.7 \%$.

Antibiotic resistance test results showed that the number of isolates resistant to three or more antibiotic classes was quite high. Multi drug-resistant of tetracycline, quinolone, fluoroquinolone and macrolides was most frequently observed. The presence of resistant $E$. coli on samples was a matter of concern. In general, when antibiotics were used, they would eliminate the susceptible bacteria strains and remain resistant bacteria. Then the resistant bacteria multiplied and become a dominant population which could transfer resistance genes (either horizontally or vertically) to other bacteria (Madigan et al., 2014). Resistance traits could be obtained from mutations, gene transfer by conjugation or transformation, transposons, integron, and bacteriophages (Cogliani et al., 2011). In fact, E. coli was the main bacteria that causes the spread of antibiotic resistance (WHO, 2017).

Tetracycline resistance was frequently reported from chicken samples (Kurnia et al., 2018; Al Azad et al., 2019). In this study, $100 \%$ of the isolates showed phenotypic resistance to tetracyclines and oxytetracyclines. These results were consistent with previous studies which reported tetracycline resistance in $97.3 \%$ of isolates (Niasono et al., 2019). Tetracycline resistance occured in chicken isolates because it was widely used as growth promoters in poultry (Kolar et al., 2002).

The tet $A$ and tet $B$ is the most common gene responsible for resistance to tetracyclines (Skockova et al., 2012). In this study, we performed the detection of tetA gene. As many as $80 \%$ of isolates that were phenotypically resistant showed the presence of tet $A$ gene. Although the remaining $20 \%$ were also phenotypically resistant but did not carry tet $A$ gene. This resistance could be caused by other mechanisms such as enzymatic inactivation or target modification (Chopra \& Roberts, 2001).

All isolates (100\%) showed erythromycin resistant. Similarly, (Talebiyan et al., 2014) reported erythromycin resistant in E. coli was $71.7 \%$. The high resistance of erythromycin was related to the impact of Mycoplasma treatment. Erythromycin was 
highly used in breeders against Mycoplasma synoviae and Mycoplasma gallisepticum.

Erythromycin-resistant E. coli was screened for the ermB gene. Although phenotypically resistant to erythromycin, genotypically no ermB gene was detected in all $E$. coli isolates. These results differ from detection of the ermB gene by Kappell et al. (2015), there were $38.9 \%$ of the ermB gene detected in $E$. coli isolates from urban waterways. It is possible that another erythromycin resistance gene encodes this phenotype.

The prevalence of gentamicin resistance phenotype in E. coli isolates was $40 \%$. The result was similar to the study conducted by Al Azad et al. (2019) showed $49 \%$ E. coli resistance to gentamicin. Gentamicin was used widely in the poultry industry with or without a combination of other antibiotics.

Genotypically, all gentamicin resistant isolates were not detected by the aac(3)-IV gene. Nevertheless, the study conducted by Choi et al. (2011) showed $46.2 \%$ and $50.7 \%$ of the $\operatorname{arc}(3)-I V$ genes in $E$. coli indicator and $E$. coli pathogenic isolates, respectively. Zarate et al. (2018) stated that there were other genes capable of coding resistance to gentamicin and other aminoglycoside antibiotics, i.e. $\operatorname{aac}(6)-I, \operatorname{aac}(6)-I I, \operatorname{aac}(3)-I, \operatorname{aac}(3)-I I, \operatorname{aac}(3)-I I I$ and $\operatorname{aac}(3)$-VII.

The resistance test for quinolone and fluoroquinolones in this study was carried out against nalidixic acid, enrofloxacin, and ciprofloxacin. Phenotypically, the resistance of this group is quite high (70-90\%). According to the study Al Azad et al. (2019), E. coli isolates from broilers experienced high resistance $(100 \%)$ to ciprofloxacin and enrofloxacin. However, different report from Niasono et al. (2019) showed lower resistance to nalidixic acid, enrofloxacin and ciprofloxacin (40.5-64.9\%). The diversity in the use of antibiotics, geographic differences, and different poultry production systems gave different patterns of resistance (Bywater et al., 2004).

The gyrA gene represented quinolone and fluoroquinolone resistance coding genes. All resistant isolates of this group were phenotypically (100\%) detected by the gyrA gene. Quinolone and fluoroquinolone resistance usually occurs due to gyrA gene mutation. Kotb et al. (2019) showed that $100 \%$ of the gyrA gene had a mutation in codon 83 (serine $\rightarrow$ leucine) in $71.3 \%$ of the quinolone and fluoroquinolone-resistant $E$. coli. In addition, the gyrA gene in the high resistance phenotype underwent a codon mutation in 87 (Asp87Asn) (4\%).

There were no isolates detected chloramphenicol resistance. Similar to the finding of Hailu \& Tefera
(2016) had reported no resistant E. coli isolates to chloramphenicol. The current study finding was distantly related to the finding of Shecho et al. (2017) who found only $3.85 \%$ of healthy broilers resistant to chloramphenicol. The different finding was reported by Halfaoui et al. (2017), the chloramphenicol resistance was medium level $(39.22 \%)$ in E. coli from broiler chickens in Algeria. Chloramphenicol was prohibited in breeding. The medium level resistance might due to the persistence of previous resistances or exposes illegal usage.

In conclusion, occurrence of resistant antibiotics in E. coli isolated from broiler chickens in Cianjur, Indonesia, was high. Multi drug-resistant was found among isolates. The high level of multi drugresistant among bacterial isolates indicates the indiscriminate use of antimicrobials in poultry sectors. In this study, not all resistant phenotypes were detected their resistance genes according to the target primers. For future studies, it was advisable to use more varied target primers.

"All authors declare that there are no conflicts of Interest".

\section{REFERENCES}

Al Azad R, Muha. Ajijur, Md. Masudur R, Ruhul A, Mst. Ismat AB, Reinhard F, Asmaul H, Ahmed SK, ATM. Badruzzaman, Mohamed EEZ, Kannika NL, Hossam MA Hafez MH. 2019. Susceptibility and multidrug resistance patterns of Escherichia coli isolated from cloacal swabs of live broiler chickens in Bangladesh. Pathogens 8(3): 118.

Andriyani M, Usamah A, Risa T. 2020. Gambaran kepekaan Escherichia coli dari peternakan ayam broiler di Desa Bojongkerta Kabupaten Sukabumi terhadap antibiotic. ARSHI Veterinary Letters 4(1): 19-20.

Bonomo RA. 2000. Multiple antibiotic-resistant bacteria in long-term-care facilities: An emerging problem in the practice of infectious diseases. Clinical Infectious Disease 31(6): 1414-1422.

Bywater R, Deluyker H, Deroover E, De Jong A, Marion $\mathrm{H}$, McConville M, Rowan T, Shryock T, Shuster D, Thomas V, Valle M, Walters J. 2004. A European survey of antimicrobial susceptibility among zoonotic and commensal bacteria isolated from food-producing animals. Journal of Antimicrobial Chemotherapy 54(4): 744-754.

Cameron A, McAllister TA. 2016. Antimicrobial usage and resistance in beef production. Journal of Animal 
Science and Biotechnology 7(68): 1-22.

Choi MJ, Suk-Kyung L, Hyang-Mi N, Ae-Ran K, SukChan J, Mal-Nam K. 2011. Apramycin and gentamicin resistances in indicator and clinical Escherichia coli isolates from farm animals in Korea. Foodborne Pathogens and Disease 8(1): 119-123.

Chopra I, Roberts M. 2001. Tetracycline antibiotics: mode of action, applications, molecular biology, and epidemiology of bacterial resistance. Microbiology and Molecular Biology Reviews 65(2): 232-260.

Chuah L, Ahamed-Kamal SS, Ismail MS, Tajudin FH, Gulam R. 2018. Data on antibiogram and resistnce genes harboured by Salmonella strains and their pulsed-field gel electrophoresis clusters. Data in Brief 17: 698-702.

[CLSI] Clinical and Laboratory Standards Institute. 2018. Performance Standards for Antimicrobial Susceptibility Testing. $28^{\text {th }}$ ed. Clinical and Laboratory Standards Institute. West Valley. p30-37.

Cogliani C, Goossens, H Greko, C. 2011. Restricting antimicrobial use in food animals: lessons from Europe. Microbe 6(6): 274-279.

Hailu D, Tefera G. 2016. Isolation and characterization of multidrug resistant Escherichia coli isolates from contagion syndrome poultry farm. International Journal of Current Trends in Pharmacobiology and Medical Sciences 1(2): 19-26.

Halfaoui Z, Nabil MM, Lyes MB. 2017. Serogrouping and antibiotic resistance of Escherichia coli isolated from broiler chicken with colibacillosis in center of Algeria. Veterinary World 10(7): 830-835.

Kappell AD, Maxwell SD, Neha HA, Nathan AL, Ryan JN, Krassimira RH. 2015. Detection of multidrug resistant Escherichia coli in the urban waterways of Milwaukee, WI. Frontiers in Microbiology 6: 336 .

Karen LT, Niamh PC, Diego BN, Susan CC, Paul ER, Herman WB, Alicia JP, Heather G, Nishan S, James DK, William AG. 2017. Restricting the use of antibiotics in food-producing animals and its associations with antibiotic resistance in foodproducing animals and human being: a systematic review and meta-analysis. The Lancet Planetary Health 1(8): 316-327.

Kolar M, Pantucek R, Bardon J, Vagnerova I, Typovska H, Valka I, Doskar J. 2002. Occurrence of antibiotic-resistant bacterial strains isolated in poultry. Veterinarni Medicina 47: 52-59.

Kotb DN, Wafaa KM, Mahmoud SM, Rasha MMK. 2019. Impact of co-existence of $P M Q R$ genes and QRDR mutations on fluoroquinolones resistance in Enterobacteriaceae strains isolated from community and hospital acquired UTIs. BMC Infectious Disease 19: 979.

Kurnia RS, Indrawati A, Mayasari NLPI. 2018. Molecular detection of genes encoding resistance to tetracycline and determination of plasmidmediated resistance to quinolones in avian pathogenic Escherichia coli in Sukabumi, Indonesia. Veterinary World 11(11): 1581-1586.

Madigan MT, Martinko JM, Bender KS, Buckley FH, Stahl DA. 2014. Brock Biology of Microorganisms. $14^{\text {th }}$ ed. Pearson International. Illinois. p1006.

Markey, Bryan, Finola L, Marie A, Ann C, Dores M. 2013. Clinical Veterinary Microbiology. $2^{\text {nd }}$ ed. Elsevier. China. P239-248.

Masruroh CA, Mirnawati BS, Hadri L. 2016. The occurance of extended spectrum $\beta$-lactamaseproducing Esherichia coli from broiler feces in Bogor. Jurnal Sain Veteriner 34(1): 42-49.

Mohammad H, Mayhoub AS, Cushman M, Seleem MN. 2015. Anti-biofilm activity and synergism of novel thiazole compounds with gly-copeptide antibiotics against multidrug-resistant Staphylococci. The Journal of Antibiotics 68(4): 259-266.

Nawaz M, Khan SA, Tran Q, Sung K, Khan AA, Adamu I, Steele RS. 2012. Isolation and characterization of mutidrug-resistant Klebsiella spp. isolated from shrimp imported from Thailand. International Journal of Food Microbiology 155(3): 179184.

Niasono $A B$, Hadri L, Trioso P. 2019. Antibiotic resistance to Escherichia coli isolated from broiler farms in Subang District, West Java Province. Jurnal Veteriner 20(2): 187-195.

Shecho M, Naod T, Jelalu K, Yimer M. 2017. Cloacael carriage and multidrug resistance Escherichia coli O157:H7 from poultry farms, Eastern Ethiopia. Journal of Veterinary Medicine Article ID 8264583.

Skockova A, Cupakova S, Karpískova R, Janstova B. 2012. Detection of tetracycline resistance genes in Escherichia coli from raw cow's milk. Journal of Microbiology, Biotechnology and Food Sciences 1: 777-784.

Solomon SL, Oliver KB. 2014. Antibiotic resistance threats in the United States: Stepping back from the brink. American Academy of Family Physicians 89(12): 938-941.

Song JH, Chang HH, Suh JY, Ko KS, Jung SI, Oh WS, Peck KR, Lee NY, Yang $Y$, Chongthaleong $A$, Aswapokee N, Chiu C, Lalitha MK, Perera J, Yee TT, Kumararasinghe $G$, Jamal F, Kamarulazaman A, Parasakthi N, Van PH, So T, Ng TK, ANSORP 
Study Group. 2004. Macrolide resistance and genotyping characterization of Streptococcus pneumoniae in Asia countries: a study of the Asian network for survellance of resistant pathogens (ANSORP). Journal of Antimicrobial Chemotherapy 53(3): 457-463.

Sukhumungoon P, Nakaguchi $\mathrm{Y}$, Ingviya $\mathrm{N}$, Pradutkanchana J, Iwade $Y$, Seto $K$, Son, R, Nishibuchi $M$, Vuddhakul V. 2011. Investigation of stx $_{2}{ }^{+}$eae $^{+}$ Escherichia coli O157: $\mathrm{H} 7$ in beef imported from Malaysia to Thailand. International Food Research Journal 18: 381-386.

Talebiyan R, Mehdi K, Faham K, Mohammad R. 2014. Multiple antimicrobial resistance of Escherichia coli isolated from chickens in Iran. Veterinary Medicine International 49: 14-18.

Tilak JD. 2011. Bacterial resistance to antibiotics: A growing public health problem. MUMJ Commentary 8(1): 58-62.
Van TTH, Chin J, Chapman T, Tran LT, Coloe PJ. 2008. Safety of raw meat and shellfish in Vietnam: an analysis of Eschericia coli isolations for antibiotic resistance and virulence genes. International Journal of Food Microbiology 124(3): 217-223.

[WHO] World Health Organization. 2017. Global Priority List of Antibiotic-Resistant Bacteria to Guide Research, Discovery, and Development of New Antibiotics. https://www.who.int/medicines/ publications/global-priority-list-antibiotic-resistantbacteria/en/. Download: August 7, 2020.

[WHO] World Health Organization. 2019. Antimicrobial Resistance. https://www.who.int/ antimicrobial-resistance/en/. Download: November 20, 2020.

Zarate SG, Luisa DCC, Raul B, Julia R, Anrdreas GS, Agatha B. 2018. Overcoming aminoglycoside enzymatic resistance: design of novel antibiotics and inhibitors. Molecules 23(2): 284. 